\title{
COVID-19 AND LABOR MIGRATION OF NEED, DESPAIR, POVERTY FROM UKRAINE TO EUROPE
}

\section{Oksana Koshulko}

Alfred Nobel University, Dnipro city, Ukraine

\section{Sergii V. Dzholos}

Bohdan Khmelnytsky National University of Cherkasy, Cherkasy, Ukraine

OMESTE

JEL Category: J61, J65, J71, J81, J83

\begin{abstract}
The article presents the results of research concerning the current issues of Ukrainian labor migrants to Poland and other European countries before and during the pandemic, as well as results of the analysis of the actions of the current Ukrainian Government's attempts to stop migration flows from Ukraine. Primary and secondary sources of information have been used in the process of preparing the article. Primary data was collected using qualitative case studies conducted among labor migrants in Poland and Ukraine from 2018 to 2020. Secondary data was taken from Ukrainian, Polish, and other international sources of information. In particular, the secondary data of information was taken from open publications and open sources. Also, in the article, the four categories of need, which pushed Ukrainian labor migrants to work abroad, have been identified and characterized. Besides, an evaluation has been given of the Ukrainian Government's performance, at the time when it was attempting to stop the migration flows from Ukraine to other countries of Europe but left no alternatives for its workers within the country. In general, analysis of challenges of Ukrainian labor migration to other countries of Europe during the international COVID-19 pandemic is a topical and timely subject for research.
\end{abstract}

Keywords: COVID-19, Ukrainian labor migration, Ukraine, Poland, Europe, immigration policy

\section{INTRODUCTION}

This article is an analysis of current issues of Ukrainian labor immigrants in Poland and other European countries, who are accepting Ukrainian labor migrants when COVID-19 is spreading throughout the world. The article is timely and topical.

The address of the corresponding author: Oksana Koshulko 㪯; oksanakoshulko2015@gmail.com
According to the evaluation of an expert on Ukrainian migration,

'Ukrainian migrants are a huge source of labor across Europe, making up the largest group of migrant workers on the continent' (Melanovski, 2020).

The article is also an analysis and evaluation of the manipulative activity of the current Ukrainian Government, which is forcibly stopping migration flows from Ukraine to other countries of Europe 
without offering any alternative or re-integration strategy.

The methodology of the research consisted of primary and secondary sources of information. The primary data was collected from qualitative case studies conducted among Ukrainian labor migrants in Poland and Ukraine from 2018-2020, before and during the pandemic. The research was conducted during 2018-2019 in Poland and during 2020 in Ukraine. Twenty former and current Ukrainian labor migrants participated in the faceto-face research from 2018-2019 and online during 2020.

The secondary data for the article was taken from Ukrainian, Polish, and other international sources of information.

In particular, the secondary data of information was taken from open publications and open sources, such as:

- The Ministry of Family, Labour, and Social Policy of Poland.

- The Service of the Deputy Prime Minister of Ukraine.

- The Central European Institute (in Polish: Instytut Europy Środkowej).

- The EWB Project - Europe Without Barriers.

- The National Bank of Poland (in Polish: Narodowy Bank Polski).

- The Outsourcing Portal.

- From other sources of information.

The article is prepared based on earlier research by the author conducted in recent years in Poland and other countries. Other examples of publications by the author on this topic are 'Exploring Women's Migration from Ukraine to Other Countries from the end of the 1980s to the 2020s' (Koshulko, 2020); the article 'Field Studies on Female Immigrants in their Host Countries: Challenges and Prospects' (Koshulko, 2019); the article 'The role of Ukrainians in the economic growth of Poland' (Koshulko, \& Koshulko, 2016); the article "The "Value of Life and Labor" of Ukrainian Migrants Abroad' (Koshulko, 2015) and the article 'The Importance of Medical Insurance and Social Security for Ukrainian labor migrants in Poland' (Koshulko, 2018), among others.

This article is ideologically close and like recent papers by Ukrainian, Polish, and scientists of other nationalities, who have explored this topic.
For example, the Polish scientist B. SkoczyńskaProkopowicz conducted statistical research of Ukrainians in Poland in recent years (SkoczyńskaProkopowicz, 2018).

In 2020 a group of Polish scientists, including $P$. Strzelecki, J. Growiec, and R. Wyszyński from the National Bank of Poland, published a paper on the contribution of immigration from Ukraine to economic growth of Poland (Strzelecki, Growiec, \& Wyszyński, 2020).

Also, in 2020 the Ukrainian scientists, R. Minich, and $P$. Kravchuk wrote a research paper on the impact of the pandemic on the activity of Ukrainian Labor Migrants in Hungary, Poland, the Czech Republic, and Italy. Their paper was entitled 'The Impact of COVID-19 on Ukrainian Labour Migrants in Czechia, Hungary, Poland, and Italy' (Minich, \& Kravchuk, 2020).

The current article explores two important goals. The first is an analysis of the situation of Ukrainian labor migrants before and during the pandemic in Poland and other European countries.

The second goal is an evaluation of the actions and efforts of the Ukrainian Government, which tried forcibly to stop the migration flows from Ukraine through manipulating the situation with COVID-19.

\section{UKRAINIAN LABOR MIGRATION TO POLAND BEFORE THE PANDEMIC}

Migration flows from Ukraine to Poland became unprecedentedly high in recent years. Among the immigrants were students, marriage partners, scientists, businesspeople, cultural visitors, and, of course, labor migrants. This article only considers labor migration from Ukraine.

The results of case studies, conducted in Poland and Ukraine among Ukrainian labor migrants, show four categories of need that have pushed Ukrainians to work abroad. These categories are defined and combined under the title 'Labor Migration due to Need, Despair, and Poverty.'

The first category of 'need and poverty' consists of those labor migrants pushed to work abroad due to the extreme poverty of their families in Ukraine. These people did not have a job in their native 
Ukraine, had only minimum savings for survival, and lacked any opportunity to meet basic needs in their home country.

The second category of 'despair' consists of the migrants who sought work abroad to hide from the war and mobilization in Ukraine. This category excludes real refugees and asylum seekers who, as shown in case studies, sometimes survived miraculously during the first stages of occupation and war in Ukraine.

The third category of 'needs' is the category of those migrants, who had a job in Ukraine before, but went to work abroad seeking better job and higher earnings in Poland or other European countries.

The fourth category of 'need' is the migrants, who seek not only higher pay in European countries but also want to enrich their lives by traveling in Europe and other interesting places worldwide.

Previous research by the author (Koshulko, \& Koshulko, 2016) and data of the Ministry of Family, Labor, and Social Policy of Poland (Ministry, 2020), make it possible to analyze the number of work permits issued to Ukrainian labor migrants from 2010 to 2020 in Poland (excluding illegal workers from Ukraine) (Table 1).

Table 1. The number of work permits issued in Poland for Ukrainian labor migrants (the data for the first half of the 2010-2020 years), in persons and percentages

\begin{tabular}{|l|r|r|r|}
\hline Years & $\begin{array}{l}\text { The total } \\
\text { number } \\
\text { of work } \\
\text { permits } \\
\text { issued in } \\
\text { Poland }\end{array}$ & $\begin{array}{l}\text { The total } \\
\text { number of } \\
\text { work } \\
\text { permits } \\
\text { issued to } \\
\text { Ukrainians }\end{array}$ & $\begin{array}{l}\text { The } \\
\text { difference } \\
\text { between } \\
\text { the } \\
\text { numbers }\end{array}$ \\
\hline $\begin{array}{l}\text { The first } \\
\text { half of } \\
2010\end{array}$ & 15839 & 4957 & 10882 \\
\cline { 2 - 4 } & $100 \%$ & $31 \%$ & $69 \%$ \\
\hline $\begin{array}{l}\text { The first } \\
\text { half of } \\
2015\end{array}$ & 25289 & 19079 & 6210 \\
\cline { 2 - 4 } $\begin{array}{l}\text { The first } \\
\text { half of } \\
2020\end{array}$ & $100 \%$ & $75 \%$ & $25 \%$ \\
\cline { 2 - 5 } & $100 \%$ & $73 \%$ & $27 \%$ \\
\hline
\end{tabular}

The data: Ministry of Family, Labor, and Social Policy of Poland (Ministry, 2020).
Table 1 shows that migration from Ukraine to Poland has systematically increased during the first two decades of the 21 st century.

In the second decade of the 21st century, the number of works permits for Ukrainians in Poland was over 30 times greater than in the period 2010 to 2020 (from 4957 permits in 2010 to 145067 in 2020).

From 2015 to 2020, the number of works permits for Ukrainians in Poland was over 7 times greater (from 19079 work permits in 2015 to 145067 in 2020).

As a result, during the second decade of the $21 \mathrm{st}$ century, the percentage of total work permits issued to Ukrainians in Poland more than doubled from 2010 to 2015 (from $31 \%$ in 2010 to $75 \%$ in 2015).

The growth curve of work permits for Ukrainians in Poland during 2010-2020 is shown in Figure 1 using the data of the Ministry of Family, Labor, and Social Policy of Poland (Ministry, 2020).

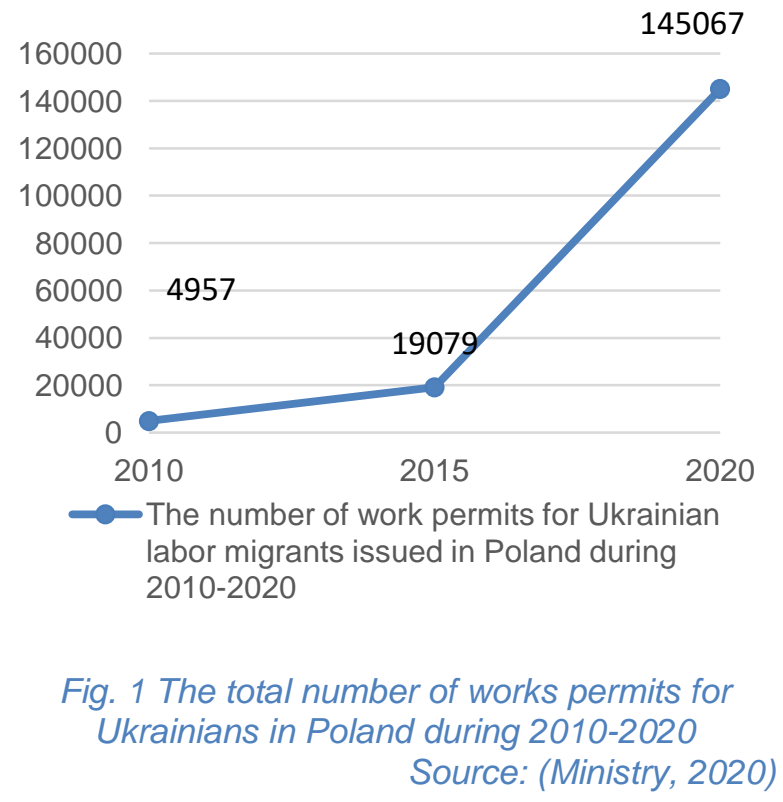

Research by the authors, conducted in Poland (Koshulko, \& Koshulko, 2016) and the data of the Ministry of Family, Labor, and Social Policy of Poland on labor migrants (Ministry, 2020) confirm that Poland became one of the most active recipient countries for Ukrainian labor migration during the first two decades of this century. 


\section{UKRAINIAN LABOR MIGRATION TO POLAND DURING THE PANDEMIC}

Since the spring of 2020 , during the period of quarantine, borders have been closed at home and abroad to international labor migration.

This means families of Ukrainian labor migrants have lost the means of survival. This was most difficult for the first category of the migrants, who are the most vulnerable of the Ukrainian labor migrants.

The characteristics of the first category of 'need and poverty' are as given above:

'labor migrants pushed to work abroad due to the extreme poverty of their families in Ukraine. Those who had no job in their native Ukraine, who had minimum savings and lacked any opportunity to meet their basic needs in their native country'.

In the opinion of $\mathrm{J}$. Melanovski, in his article entitled 'Millions of Ukrainian migrant workers forced to search for employment in Europe under unsafe conditions,' Ukrainian labor migrants searched abroad for 'much-needed work' (Melanovski, 2020).

The Outsourcing Portal confirmed that even in the pandemic period, Polish employers wanted to employ Ukrainian workers and Ukrainians wanted to work in Poland (The Outsourcing Portal, 2020):

'The Coronavirus epidemic has reduced the number of jobs offers for employees from Ukraine. Companies in Poland withheld recruitment or decided to employ Poles. It turns out, however, that it was only a temporary lull. Already, employers' activity on our application is even greater than before the epidemic. This is good news not only for Ukrainians, among whom the interest in working in Poland has not decreased but also for the Polish labor market, which still needs staff from the East. Manufacturing, logistics, and service companies show the greatest interest.'

As a result, during the pandemic Ukrainian labor migrants continue to work in Poland, even when they faced many difficulties there due to 2-week quarantine and other barriers.

Not only do the migrants need jobs and are ready to face the difficulties and barriers but Polish employers want to employ Ukrainians because their labor is much cheaper than that of Poles.

\section{IMPORTANCE OF UKRAINIAN LABOR MIGRATION FOR OTHER EU COUNTRIES DURING THE PANDEMIC OF 2020}

During the pandemic of 2020, it became clear how important Ukrainian labor migrants are to the economies of other European countries as well as Poland.

In the opinion of J.Melanovski, 'Millions of Ukrainian migrant workers who returned to their native country at the beginning of the coronavirus pandemic are now searching for opportunities to return to Europe for much-needed work as quarantine measures are relaxed both in Ukraine and across Europe' (Melanovski, 2020).

These labor migrants resumed their search for opportunities to work in EU countries because the pandemic showed very clearly how important the Ukrainian labor migrants are to the European economy.

Also, J. Melanovski confirmed the opinion of the author concerning the importance of Ukrainian labor migrants to employers in Poland, the Czech Republic, Germany, and other countries of the E.U. during the pandemic (Melanovski, 2020): 'Approximately 2 million Ukrainian migrant workers reside in nearby Poland where they account for 2.5 percent of the country's GDP. Large numbers also work in Italy, the Czech Republic, Finland, and Germany' (Melanovski, 2020).

As a result, to employ Ukrainian labor migrants in Finland, the Czech Republic, Germany, and other countries of the E.U. employers in these countries were ready to organize charter flights to bring migrants from Ukraine for seasonal jobs during the pandemic.

To attract Ukrainian labor migrants, the employers in European countries were ready to bear the cost of COVID-19 tests and the 2-week quarantine for arriving Ukrainian labor migrants. They did this because Ukrainian labor migrants are extremely important to them, particularly for seasonal work.

It was of paramount importance to solve the challenge facing international employers and Ukrainian labor migrants in 2020. It was solved by the Ukrainian Ambassadors, in particular the Service of the Deputy Prime Minister of Ukraine, 
and Ambassadors in the countries receiving Ukrainian labor migration.

An example is the Finnish employers (mostly farmers), who needed Ukrainian seasonal labor workers, where the problems were resolved at the level of Ambassadors of Ukraine and Finland.

The data of the Service of the Deputy Prime Minister of Ukraine, the Ambassador Extraordinary, and Plenipotentiary of Finland to Ukraine shows that farmers of Finland expected 15,000 Ukrainian workers in 2020. His opinion about the labor of the Ukrainian labor migrants in Finland was cited as (The Service, 2020):

'Finland is facing a severe shortage of seasonal employees. Ukrainian workers have shown themselves to be responsible, honest, and hardworking and we look forward to the opportunity this year to have them back to work in agriculture and forestry, as well as other sectors (The Service, 2020).

The analysis of evaluations of international employers from countries of the E.U. conducted in 2020 showed that, despite the pandemic, Ukrainians are still very much welcome at the labor markets of many E.U. countries as seasonal and non-seasonal workers.

\section{CONFRONTATION BETWEEN UKRAINIAN LABOR MIGRANTS AND THE CURRENT UKRAINIAN GOVERNMENT IN 2020}

The recent confrontation between Ukrainian labor migrants and the current Ukrainian Government, who were attempting to forcibly stop the migration flows from Ukraine to other countries, in particular the E.U. countries, showed very clearly that this Government is unable to cope with both the pandemic and the flow of migrants from Ukraine.

As soon as the Government realized it was unable to control the situation, it decided to close the borders, so creating a new 'Iron Curtain' around Ukraine in 2020.

What does that mean? Ukraine is a poor country due to incompetent management by the government, which means that the population remains poor and the number of migrants leaving the country remains remarkably high.
During the pandemic, the situation in the country became worse. It appears that the reasons for leaving given by all migrants in 2020, until then having fallen into four categories as explained above, now all fell into the first category.

The Ukrainian Government, having made Ukrainians one of the poorest nations in Europe, finding themselves in 2020 with no strategy for the survival of the nation or the control of labor migration, decided to prohibit all migration from Ukraine to work abroad. Ukrainian workers wishing to migrate became hostages due to the pandemic and the incompetency of the Government, and as a result, remained in Ukraine without means of subsistence.

The Government failed to create opportunities for employment for Ukrainian workers within their own country.

They were also unable to offer realistic plans for the employment of Ukrainian workers at home and so decided to close the borders to prevent people from leaving to work abroad.

These actions of the Government revealed its incompetency, which, rather than finding a solution, merely created a new 'Iron Curtain' between Ukraine and the developed world.

In the opinion of $\mathrm{J}$. Melanovski, the situation was solved only because of a 'widespread outcry' (Melanovski, 2020):

'In April the Ukrainian government attempted to stop charter flights leaving for Finland and the United Kingdom. Due to widespread outcry over the lack of work within the country and the inability of workers to leave the country, the Zelensky government announced it would allow workers to leave only with a guaranteed three-month minimum contract, health insurance covering coronavirus, housing, and transportation to their work country and back'.

The evaluation of actions and efforts of the Ukrainian Government is extremely negative, following its attempts to stop the flow of migrants from Ukraine under the guise of managing COVID19 , so leaving the workers with no alternative other than to work at home.

What could the Government have done before closing the borders of Ukraine? 
Before creating a new 'Iron Curtain 2020' in the country the Government could have considered the following steps:

A fresh impetus to restart the economy, which is failing due to the high level of corruption in all fields of economic activity, a lack of investment, and a lack of opportunities for the development of small and medium-sized businesses.

Measures to put a stop to the ever-growing share of business within the black economy of the country.

Systems to give guarantees and attractive credits for residents and non-residents, so encouraging and assisting all kinds of small and medium-sized businesses in the country.

Measures to stabilize the national currency to prevent the systematic impoverishment of the population and other important changes for the effective management of state institutions.

\section{CONCLUSIONS}

In this article, the results of research concerning the current situation and issues of Ukrainian labor migrants in Poland and other countries of Europe before and during the pandemic is analyzed and explored.
The four categories of need, which pushed Ukrainian labor migrants to work abroad, have been identified and characterized in the article.

The first category of 'need and poverty' consisted of those labor migrants pushed to work abroad due to the extreme poverty of their families in Ukraine.

The second category of 'despair' consisted of the migrants who sought work abroad to hide from the war and mobilization in Ukraine.

The third category of 'needs' was the category of those migrants, who had a job in Ukraine before but went to work abroad seeking a better job and higher earnings in Poland or other European countries.

The fourth category of 'need' was the migrants, who seek not only higher pay in European countries but also want to enrich their lives by traveling in Europe and other interesting places worldwide.

Also, an evaluation has been given of the Ukrainian Government's performance, at the time when it was attempting to stop the migration flows from Ukraine to other countries of Europe but left no alternatives for its workers within the country.

\section{WORKS CITED}

Drabczuk, M. (2020). Ukraińscy migranci zarobkowi na polskim (nie)pewnym rynku pracy. Instytut Europy Środkowej. No. 210, Vol. 113/2020 [In Polish]. Retrieved from https://cutt.ly/gfhSI9x

Koshulko, O. (2020). Exploring Women's Migration from Ukraine to Other Countries from the end of the 1980s to the 2020s. Randwick International Social Science Journal, 1(1), 127-132, Randwick, New South Wales, Australia.

Koshulko, O. (2019). Field Studies on Female Immigrants in their Host Countries: Challenges and Prospects. MEST Journal, 7(1), 34-40, Belgrade, Serbia.

Koshulko, O., \& Gribincea, C. (2018). The Importance of Medical Insurance and Social Security for Ukrainian labor migrants in Poland. Proceedings of the 13th Edition of the International Conference on Theoretical and Applied Economic Practices 'Economic Growth in Conditions of Globalization: competitiveness, innovation, sustainability,' National Institute for Economic Research (NIER) of the Academy of Sciences of Moldova, (Vol. II, pp. 169-172), Chisinau, Republic of Moldova, October 11-12.

Koshulko, O., \& Koshulko, V. (2016, 02). The role of Ukrainians in the economic growth of Poland. International Scientific Journal 'World Scientific News', (42), 256-266, West Pomerania, Poland.

Koshulko, O. (2015, 09). The "Value of Life and Labor" of Ukrainian Migrants Abroad. International Letters of Social and Humanistic Sciences, (59), 1-8. SciPress Ltd., Bach, Switzerland. 
Melanovski, J. (2020). Millions of Ukrainian migrant workers forced to search for employment in Europe under unsafe conditions. World Socialist Web Site. Retrieved from https://cutt.ly/SfhSPG4

Minich, R., \& Kravchuk, P. (2020). The Impact of COVID-19 on Ukrainian Labour Migrants in Czechia, Hungary, Poland, and Italy. Policy Brief, Europe without Barriers, $14 \mathrm{p}$.

Ministry of Family, Labour, and Social Policy. The number of work permits issued in Poland. Retrieved from https://cutt.ly/FfhSXnr

Skoczyńska-Prokopowicz, B. (2018). Foreign labour migration of Ukrainians to Poland: statistical research from the perspective of Ukrainian studies. Zeszyty Naukowe Politechniki Śląskiej. Seria: Organizacja i Zarządzanie, Vol. 122, pp. 195-204.

Strzelecki, P., Growiec, J., \& Wyszyński, R. (2020). The contribution of immigration from Ukraine to economic growth in Poland. Narodowy Bank Polski, Warsaw, Poland, Working Paper No. 322, $46 \mathrm{p}$.

The Outsourcing Portal. (2020). Pracodawcy chcą zatrudniac, Ukraincy chcą pracowac. [In Polish]. Retrieved from https://cutt.ly/yfhSF78

The Service of the Deputy Prime Minister of Ukraine, (2020). Farmers of Finland expect 15,000 Ukrainian workers this year. Retrieved from https://cutt.ly/bfhSLwT

Received for publication: $\quad 10.09 .2020$

Revision received: $\quad 27.09 .2020$

Accepted for publication: $\quad 30.12 .2020$

\section{How to cite this article?}

Style - APA Sixth Edition:

Koshulko, O., \& Dzholos, S. V. (2021, January 15). COVID-19 and labor migration of need, despair, poverty from Ukraine to Europe. (Z. Cekerevac, Ed.) MEST Journal, 9(1), 61-67. doi:10.12709/mest.09.09.01.08

Style - Chicago Sixteenth Edition:

Koshulko, Oksana, and Sergii V. Dzholos. 2021. "COVID-19 and labor migration of need, despair, poverty from Ukraine to Europe." Edited by Zoran Cekerevac. MEST Journal (MESTE) 9 (1): 61-67. doi:10.12709/mest.09.09.01.08.

Style - GOST Name Sort:

Koshulko Oksana and Dzholos Sergii V. COVID-19 and labor migration of need, despair, poverty from Ukraine to Europe [Journal] // MEST Journal / ed. Cekerevac Zoran. - Belgrade - Toronto : MESTE, January 15, 2021. - 1 : Vol. 9. - pp. 61-67.

Style - Harvard Anglia:

Koshulko, O. \& Dzholos, S. V., 2021. COVID-19 and labor migration of need, despair, poverty from Ukraine to Europe. MEST Journal, 15 January, 9(1), pp. 61-67.

Style - ISO 690 Numerical Reference:

COVID-19 and labor migration of need, despair, poverty from Ukraine to Europe. Koshulko, Oksana and Dzholos, Sergii V. [ed.] Zoran Cekerevac. 1, Belgrade - Toronto : MESTE, January 15, 2021, MEST Journal, Vol. 9, pp. 61-67. 